\title{
KNEE MUSCLE TORQUE AND H:Q RATIO CHANGES BEFORE ACL SURGERY AND AFTER REHABILITATION
}

\author{
Dovilė Parulyte் ${ }^{1}$, Nerijus Masiulis ${ }^{1}$, Vaida Aleknavičiūtè $\dot{1}^{1,2}$, Rima Solianik $^{1}$, Gintarẻ Dargevičiūtė ${ }^{1}$, \\ Albertas Skurvydas ${ }^{1}$, Vytautas Streckis ${ }^{1}$ \\ Lithuanian Academy of Physical Education ${ }^{1}$, Kaunas, Lithuania \\ Šiauliai State College ${ }^{2}$, Šiauliai, Lithuania
}

\begin{abstract}
Research background and hypothesis. Anterior cruciate ligament (ACL) of the knee joint is often quite a fragile structure of the knee. After the rupture of ACL neuromuscular control worsens and sensorimotor system breaks down (Risberg et al., 2007), muscle activation is poor and muscle strength decreases (Croce, Miller, 2006). Some authors have reported greater strength loss in quadriceps femoris than in hamstring femoris muscle (BuschJoseph et al., 2001; Neeter et al., 2006), therefore we hypothesized that strength loss in knee extensors may affect hamstring/quadriceps torque (H:Q) ratio.

Research aim of this study was to investigate knee extensors and flexors isometric and dynamic torque and $\mathrm{H}: \mathrm{Q}$ ratio alterations before ACL surgery and after rehabilitation.

Research methods. Ten volunteers with ACL ruptured knee where tested before surgery and after rehabilitation. Isokinetic dynamometer was used for this testing. Maximal isometric torque was performed during flexion and extension at $90^{\circ}, 60^{\circ}$ knee angles. Dynamic torque was performed at $30,180,300^{\circ} / \mathrm{s}$ angular velocities.

Research results. Results of this study show that after rehabilitation isometric and dynamic torque of the involved leg decreased. Isometric flexion and extension torque of the uninjured leg was greater than that of the injured leg, but after rehabilitation the extension torque of the injured leg was lower than that before surgery.

Discussion and conclusions. Before ACL surgery and after rehabilitation quadriceps femoris muscle torque of the uninjured leg was more affected than hamstring femoris muscle torque. After rehabilitation H:Q ratio of the injured leg was not dependent on angular velocity and knee joint angle.
\end{abstract}

Keywords: maximal voluntary torque, muscle balance, muscle contraction.

\section{INTRODUCTION}

A nterior cruciate ligament (ACL) of the knee joint is often quite a fragile structure of the knee. After the rupture of ACL neromuscular control worsens and sensorimotor system breaks down (Risberg et al., 2007), muscle activation is poor and muscle strength decreases (Croce, Miller, 2006). The ratio of maximal isokinetic hamstring muscle strength relative to maximal isokinetic quadriceps muscle strength ( $\mathrm{H}: \mathrm{Q}$ ratio) is a parameter commonly used to describe the muscle strength properties about the knee joint (Aagaard et al., 1998). Normal H:Q ratio for healthy people is $0.5-0.8$ (Holcomb et al., 2007). The H:Q ratio is greater at the highest velocity $\left(0.8 \pm 0.1\right.$ at $\left.360^{\circ} / \mathrm{s}\right)$ compared to the lowest angular velocity $(0.47 \pm 0.2$ at $30 \%$ s $)$ 
(Hewett et al., 2008). If $\mathrm{H}: \mathrm{Q}$ ratio is closer to 1 , the hamstring muscles are stronger and knee joint is more stable (Aagaard et al., 1998). Isokinetic and isometric different muscle group testing is applied to assess muscle strength recovery, and this enables us to know the H:Q ratio between healthy and unhealthy leg muscles (Rosene et al., 2001) and then decide whether the patient is able to return to sport (Keays et al., 2000).

To our knowledge, there is no detailed study which compare knee extensors and flexors isometric and dynamic torque and the $\mathrm{H}: \mathrm{Q}$ ratio in one study after ACL rupture and how these parameters change after 3 months of rehabilitation. Some authors have reported greater strength loss in quadriceps femoris than in hamstring femoris muscle (Busch-Joseph et al., 2001; Neeter et al., 2006), therefore we hypothesized that strength loss in knee extensors may affect $\mathrm{H}: \mathrm{Q}$ ratio. Therefore, the aim of this study was to investigate knee extensors and flexors isometric and dynamic torque and $\mathrm{H}: \mathrm{Q}$ ratio alterations before ACL surgery and after rehabilitation.

\section{RESEARCH METHODS}

The study was accomplished in accordance with the principles of the Declaration of Helsinki, concerning the ethics of experimenting with humans. Ten untrained males with left leg ACL rupture took part in this study (their mean age was $28.4 \pm 7.1$ years, height $-179.8 \pm 8.5 \mathrm{~cm}$, weight $76.0 \pm 14.0 \mathrm{~kg}$.). The inclusion into the research criteria were as follows: 1) during the surgery not more severe than grade I cartilage violation was observed; 2) the other knee joint was not damaged; 3 ) the subjects were not older than 35 years; 4) three or fewer months had passed from ACL injury to surgery. The exclusion criteria were as follows: 1) previously they had had knee injury or had undergone surgery; 2) they had osteoarthritis or posterior cruciate ligament rupture; 3) had II-IV grade knee cartilage damage.

Isokinetic dynamometer (Biodex Medical System 3, Shirley, New York, USA) was used for the measurements applied.

Isometric maximal voluntary contraction (MVC) torque measurement. MVC torque was measured isometrically when the leg was fixed at the knee joint at $90^{\circ}$ and $60^{\circ}$ degrees and the subjects were asked to increase maximal flexion and extension torque and to hold it for $5 \mathrm{~s}$. The procedure was repeated 3 times, there was $1 \mathrm{~min}$ rest between repetitions and the highest torque was used for calculation. The participants were encouraged to reach maximal torque and they were able to see their achieved torque on the screen.

Dynamic muscle torque measurement. Concentric isokinetic torque for extension and flexion (injured and uninjured legs) was measured using a isokinetic dynamometer at randomly ordered 3 angular velocities: 30,180, and $300 \%$ s. We asked the subjects to flex and extend their knees as fast as they could. There was 1 min rest between the tests at different velocities.

H:Q ratio. Concentric and isometric $\mathrm{H}: \mathrm{Q}$ strength ratio is calculated by dividing maximal concentric knee flexor (hamstring) moment by the maximal concentric knee extensor (quadriceps) moment obtained at a given joint angular velocity (Aagaard et al., 1998).

Rehabilitation programme. Rehabilitation started 2 weeks after surgery: physiotherapy, massage, electrical stimulation (16 times, 3 times per week). After 16 procedures the treatment was continued in the gym. During the physiotherapy procedure ( $45 \mathrm{~min}$ ) the range of motion, strength, balance and coordination exercises were applied. During the electrotherapy procedure $(30 \mathrm{~min})$ we applied electrostimulation (Neuro Trac, Sports $X L$, Hampshire, $U K)$, at the intensity of $20 \mathrm{~Hz}$, exercises in the gym and swimming pool (30 min), and a range of motion and strength exercises. To reduce pain, the patients were recommended to apply freezing compresses at the knee joint.

Organization of the research. The subjects performed warm-up exercises which consisted of 5 minutes of veloergometric exercise at the intensity that corresponded to the heart rate (HR) of 130-150 beats / min (about $70 \%$ of maximum HR). HR was measured using a Polar HR recorder (Polar Electro). After 5 min interval we measured maximal voluntary leg flexion and extension (at $90^{\circ}, 60^{\circ}$ of the knee joint) torque and dynamic muscle torque at 30,180 , and $300 \%$ s velocities. The testing was carried out 2 times: 1) before ACL surgery; 2) 3 months after rehabilitation.

Statistical analysis. The research data were processed using Microsoft Excel 2007 program mathematical statistical analysis. The data are reported as group mean values \pm standard deviations. The mean peak torque and the $\mathrm{H}$ :Q ratio were compared between groups using a Student's $t$ test. The level for statistical significance was set to an alpha level of $\mathrm{p}<0.05$. 


\section{RESEARCH RESULTS}

After rehabilitation we found statistically significant differences $(\mathrm{p}<0.05)$ between injured and uninjured legs, when the leg at the knee joint was flexed 60 and 90 degrees (Table 1). After rehabilitation MVC torque of the injured and uninjured legs flexion decreased at $60^{\circ}$ and $90^{\circ}$ knee angles, but we did not find any significant difference.

Extension MVC torque significantly $(\mathrm{p}<0.05)$ differed between the ruptured and the unruptured leg before surgery and after rehabilitation when the leg at the knee joint was flexed at $60^{\circ}$ and $90^{\circ}$ (Table 2). After rehabilitation the MVC torque at $60^{\circ}$ and $90^{\circ}$ of the ruptured leg significantly $(\mathrm{p}<0.05)$ decreased.

The injured leg flexion torque (Table 3) was statistically significantly lower than that of the uninjured leg at all speeds before surgery and after rehabilitation. After rehabilitation the injured leg flexion torque at $180^{\circ} / \mathrm{s}$ was significantly lower than that before surgery.

The injured leg flexion torque (Table 4) was significantly less than that of the uninjured leg at all speeds before surgery and after rehabilitation, except for the $300^{\circ} / \mathrm{s}$ speed after rehabilitation, where we did not find statistically significant difference $(p>0.05)$ between the injured and the uninjured legs.
Table 1. MVC torque of flexion of injured and uninjured legs before surgery and after rehabilitation

Note. ${ }^{*}-\mathrm{p}<0.05$ between injured and uninjured legs.

\begin{tabular}{|c|c|c|c|c|}
\hline $\mathrm{X}$ Time & \multicolumn{2}{|c|}{ Before surgery } & \multicolumn{2}{|c|}{ After rehabilitation } \\
\hline Knee joint angle & $60^{\circ}$ & $90^{\circ}$ & $60^{\circ}$ & $90^{\circ}$ \\
\hline Injured leg, $\mathrm{N} \cdot \mathrm{m}$ & $124.72 \pm 23.58$ & $73.58 \pm 14.72$ & $98.56 \pm 39.17^{*}$ & $68.32 \pm 32.1^{*}$ \\
\hline Uninjured leg, $\mathrm{N} \cdot \mathrm{m}$ & $136.42 \pm 46.45$ & $91.98 \pm 40.22$ & $125.64 \pm 37.98$ & $99.66 \pm 33.84$ \\
\hline
\end{tabular}

Table 2. MVC torque of extension of injured and uninjured legs before surgery and after rehabilitation

Note. $*-p<0.05$ between injured and uninjured legs; $\#-p<0.05$ difference before surgery and after rehabilitation.

\begin{tabular}{|l|c|c|c|c|}
\hline \multicolumn{1}{|r|}{ Time } & \multicolumn{2}{|c|}{ Before surgery } & \multicolumn{2}{c|}{ After rehabilitation } \\
\hline Knee joint angle & $60^{\circ}$ & $90^{\circ}$ & $60^{\circ}$ & $90^{\circ}$ \\
\hline Injured leg, N·m & $273.24 \pm 58.87^{* \#}$ & $235.94 \pm 41.09^{* \#}$ & $223.26 \pm 28.01 *$ & $166.42 \pm 44.27 *$ \\
\hline Uninjured leg, N·m & $347.52 \pm 69.7$ & $347.82 \pm 130.15$ & $328.34 \pm 69.19$ & $328.08 \pm 117.39$ \\
\hline
\end{tabular}

Table 3. Isokinetic flexion torque of injured and uninjured legs before surgery and after rehabilitation

\begin{tabular}{|c|c|c|c|c|c|c|}
\hline \multirow[t]{2}{*}{ Time and angular } & \multicolumn{2}{|c|}{$30 \% / \mathrm{s}$} & \multicolumn{2}{|c|}{$180^{\circ} / \mathrm{s}$} & \multicolumn{2}{|c|}{$300 \% / s$} \\
\hline & Before surgery & $\begin{array}{c}\text { After } \\
\text { rehabilitation }\end{array}$ & Before surgery & $\begin{array}{c}\text { After } \\
\text { rehabilitation }\end{array}$ & Before surgery & $\begin{array}{c}\text { After } \\
\text { rehabilitation }\end{array}$ \\
\hline Injured leg, $\mathrm{N} \cdot \mathrm{m}$ & $105.8 \pm 21.79 *$ & $92.02 \pm 21.4 *$ & $92.98 \pm 19.75^{* \#}$ & $72.7 \pm 17.08 *$ & $94.62 \pm 14.71^{*}$ & $84.94 \pm 14.26^{*}$ \\
\hline Uninjured leg, $\mathrm{N} \cdot \mathrm{m}$ & $150.04 \pm 25.76$ & $131.8 \pm 23.28$ & $123.86 \pm 32.71$ & $96.86 \pm 16.99$ & $104.2 \pm 14.61$ & $98.06 \pm 9.72$ \\
\hline
\end{tabular}

Note. $*-p<0.05$ between injured and uninjured legs; $\#-p<0.05$ difference before surgery and after rehabilitation.

Table 4. Isokinetic extension torque of injured and uninjured legs before surgery and after rehabilitation

\begin{tabular}{|c|c|c|c|c|c|c|}
\hline \multirow[b]{2}{*}{ Legs } & \multicolumn{2}{|c|}{$30 \% / s$} & \multicolumn{2}{|c|}{$180^{\circ} / \mathrm{s}$} & \multicolumn{2}{|c|}{$300 \% / s$} \\
\hline & $\begin{array}{l}\text { Before } \\
\text { surgery }\end{array}$ & $\begin{array}{c}\text { After } \\
\text { rehabilitation }\end{array}$ & Before surgery & $\begin{array}{c}\text { After } \\
\text { rehabilitation }\end{array}$ & Before surgery & $\begin{array}{c}\text { After } \\
\text { rehabilitation }\end{array}$ \\
\hline Injured leg, $\mathrm{N} \cdot \mathrm{m}$ & $219.44 \pm 69.44^{* \#}$ & $156.8 \pm 53.03 *$ & $141.7 \pm 44.47 *$ & $134.48 \pm 41.98 *$ & $147.8 \pm 33.72 *$ & $148.6 \pm 32.35$ \\
\hline Uninjured leg, $\mathrm{N} \cdot \mathrm{m}$ & $298.64 \pm 39.7$ & $273.52 \pm 59.21$ & $197.36 \pm 42.12$ & $182.2 \pm 41.32$ & $190.04 \pm 38.75$ & $166.66 \pm 31.21$ \\
\hline
\end{tabular}

Note. ${ }^{*}-\mathrm{p}<0.05$ between injured and uninjured legs; $\#-\mathrm{p}<0.05$ difference before surgery and after rehabilitation. 

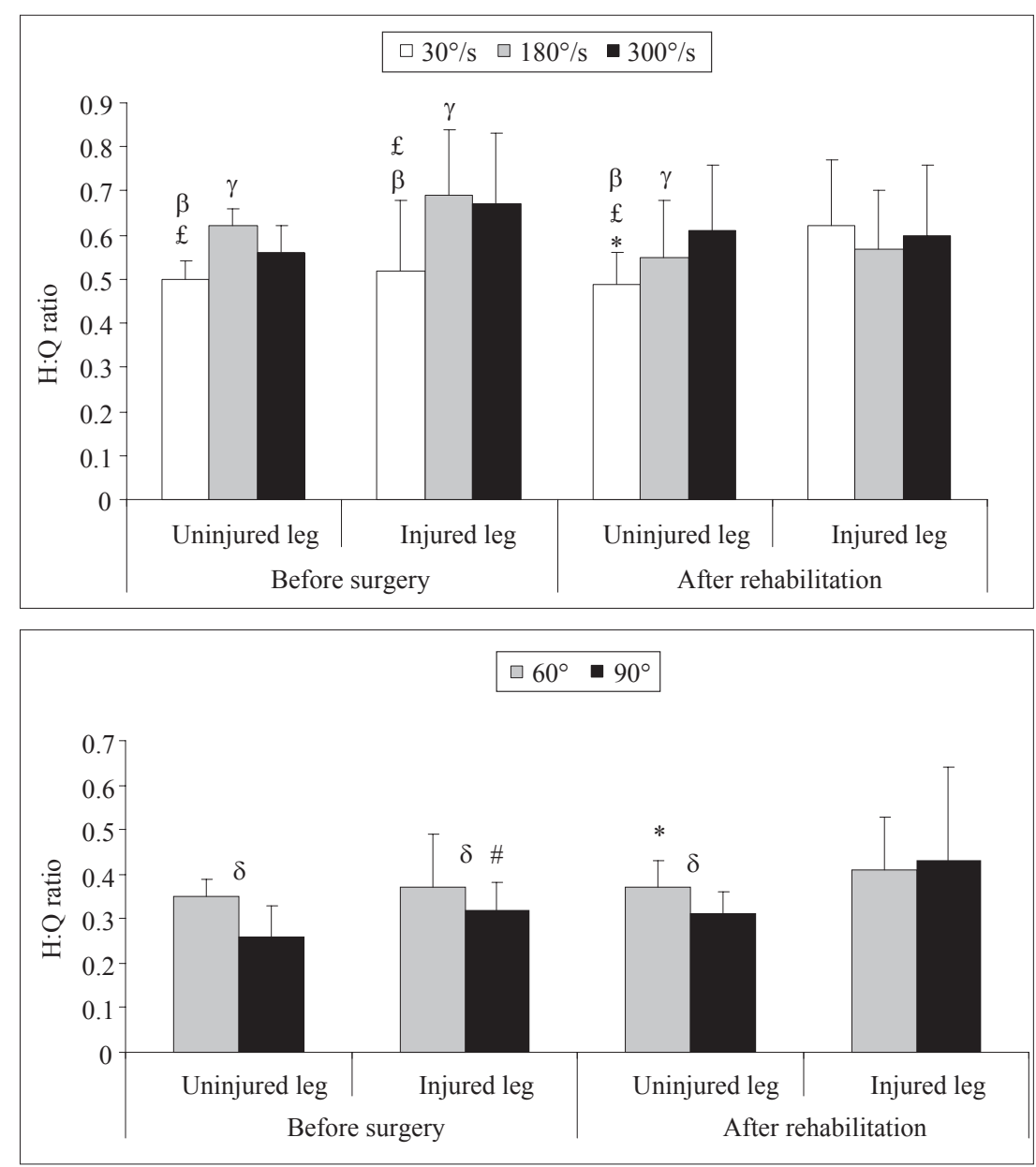

Figure 1. Isokinetic torque $\mathrm{H}: \mathrm{Q}$ ratio at different angular velocities
Note. $*-p<0.05$ between injured and uninjured legs; $£-p<0.05$ between 30 and $180^{\circ} / \mathrm{s} ; \beta-\mathrm{p}<0.05$ between 30 and $300^{\circ} / \mathrm{s}$; $\gamma-\mathrm{p}<0.05$ between 180 and $300^{\circ} / \mathrm{s}$.

Figure 2. Isometric torque $\mathrm{H}: \mathrm{Q}$ ratio at different angles
After rehabilitation, the uninjured leg $\mathrm{H}: \mathrm{Q}$ ratio at $30 \%$ angle speed was significantly lower than that of the injured leg (Figure 1). However, at a different speed we did not find significant differences between the injured and the uninjured legs before surgery and after rehabilitation. Before surgery we found significant differences between the task performance at different speeds $\left(30 / 180,30 / 300\right.$ and $\left.180 / 300^{\circ} / \mathrm{s}\right)$ when it was performed with the injured and the uninjured legs. After rehabilitation significant differences were found between all speeds when the task was performed with the uninjured leg, but when the task was performed with the injured leg significant differences were not established.

After rehabilitation, the uninjured leg $\mathrm{H}: \mathrm{Q}$ ratio at $60^{\circ}$ knee angle was significantly lower than that of the injured leg (Figure 2). After rehabilitation the injured leg $\mathrm{H}: \mathrm{Q}$ ratio at $90^{\circ}$ knee angle was significantly higher than that before surgery. But at other knee angles we did not find significant differences between the injured and the uninjured legs before surgery and after rehabilitation. H:Q ratio of the injured and the uninjured legs before surgery and of the uninjured leg after rehabilitation were dependent on the knee angle, but after rehabilitation the injured leg H:Q ratio was independent on the knee angle.

\section{DISCUSSION}

Results of this study show that after rehabilitation isometric and dynamic torque of the involved leg decreased. Isometric flexion and extension torque of the uninjured leg was greater than that of the injured leg, but after rehabilitation the extension torque of the injured leg was lower than that before surgery. After rehabilitation H:Q ratio of the injured leg was not dependent on the angle velocity and the knee joint angle.

Isometric MVC torque. We found that after rehabilitation isometric extension torque of the involved leg decreased. Before surgery and after rehabilitation the extension torque of the involved leg was lower than that of the uninvolved leg. After rehabilitation flexion torque was lower in the involved leg than that in the uninvolved leg. Therefore we suggest that ACL rupture affects isometric extension torque reduction, but it does 
not affect flexion torque. Reflex inhibition of the lower motor neurons, pain, inadequate training, muscle disuse have been shown to cause significant atrophy of type I and type II muscle fibers of the quadriceps and that can lead to quadriceps deficit (Pua et al., 2008).

We found that after rehabilitation the quadriceps and hamstrings muscle torque of the involved leg decreased, but the one of the uninvolved leg did not change. However, we found different results than those of other researchers. T. L. Chmielewski et al. (2004) found, that ACL rupture affected quadriceps femoris muscle torque reduction not only in the involved leg but also in the uninvolved leg. The differing reports found in current literature may be partly explained by differences in the rehabilitation programs and the fact that the measurements were done at various points in time. We think that our results differ, because the patients had all three months of rehabilitation, and the uninvolved leg strength restored, and the involved leg strength did not manage to fully recover.

Dynamic torque. Maximal dynamic extension and flexion torque was registered when the angle velocity was the lowest. These findings coincide with the results of many researchers who indicate that the size of the torque is dependent on the joint angle (Aagaard et al., 1998; Croce, Miller, 2006) and angle velocity (Hiemstra et al., 2004). For healthy people the maximum torque of the hamstring muscle is reached at 30 and $180^{\circ} / \mathrm{s}$ angular velocity, and quadriceps muscle is the strongest at $60 \% \mathrm{~s}$ angular velocity (Itoh et al., 1992). These data confirm the results of our study claiming that at lower speed flexion and extension torque is the highest. We found that after rehabilitation dynamic torque of the involved leg decreased. A. Clair Gibson et al. (2000) also found that quadriceps and hamstrings peak torque values were significantly decreased in ACL deficient compared to the uninvolved limb. A. Czamara et al. (2011) observed 9\% deficit in extensor muscle strength measured under isokinetic conditions of the involved knees compared to the uninvolved knees. Our results led us to conclude that the physiotherapy was of too low intensity and that the period of physiotherapy should be extended for patients.

Dynamic and isometric torque $H: Q$ ratio. We found that after rehabilitation $\mathrm{H}: \mathrm{Q}$ ratio of the involved leg was higher than that of the uninvolved leg at $30^{\circ} / \mathrm{s}$ angular velocity and $60^{\circ}$ knee angle. We believe that this is due to the fact that after the rehabilitation the quadriceps muscle torque of the involved leg decreases more than the hamstring muscle torque, thus reducing the torque difference between these muscle groups (i. e. H:Q ratio approaching 1). After rehabilitation $\mathrm{H}: \mathrm{Q}$ ratio of the involved leg is not dependent on the angle velocity and knee joint angle. Our data do not coincide with the data in M. J. Rosene et al. (2001) study where H:Q ratio is dependent on the angular velocity and joint angle. It is argued that in order to avoid the hamstrings muscle and knee joint injuries, the optimal H:Q ratio should be not less than 0.6. This may change with the velocity in which strenght is tested. P. Kannus (1988) found that the rate of this ratio must be calculated individually for all patients, because each patient is different and $\mathrm{H}: \mathrm{Q}$ ratio is also different.

H. Lund-Hanssen et al. (1996) measured H:Q ratio after ACL surgery and found that $\mathrm{H}: \mathrm{Q}$ ratio of the injured leg is higher at higher angle velocity $\left(240^{\circ} / \mathrm{s}\right)$ compared to the one of the uninjured leg, but at lower angle velocity $\left(60^{\circ} / \mathrm{s}\right)$ they did not find significant differences. P. Kannus (1988) also found that H:Q ratio of the injured leg was higher at higher angle velocity $\left(180^{\circ} / \mathrm{s}\right)$ compared to the one of the uninjured leg. We found, that at $180^{\circ} / \mathrm{s}$ angular velocity $\mathrm{H}: \mathrm{Q}$ ratio reduced more than at $30 \%$, and we think that this is due to quadriceps muscle torque reduction and fast muscle fiber atrophy.

We found that concentric torque at different velocities showed that bigger differences between injured and uninjured legs were visible at higher velocity. Lower H:Q ratio between injured and uninjured legs shows that muscle torque is not yet full reached and needs further rehabilitation (Aagaard et al., 1998). We can make a conclusion that $\mathrm{H}: \mathrm{Q}$ ratio is higher at higher velocity; $\mathrm{H}: \mathrm{Q}$ ratio after ACL surgery depend on quadriceps muscle torque reduction; the goal of rehabilitation should be the achievement of $\mathrm{H}: \mathrm{Q}$ ratio of the injured leg equal to the one of the uninjured leg. It is very important to calculate $\mathrm{H}$ : $\mathrm{Q}$ ratio because it was found that the risk of ACL rupture depended on the H:Q ratio (Devan et al., 2004) and strength imbalances were associated with the risk of injury in sports (Pua et al., 2008). 


\section{CONCLUSIONS AND PERSPECTIVES}

Before ACL surgery and after rehabilitation quadriceps femoris muscle torque of the uninjured leg was more affected than hamstring femoris muscle torque. After rehabilitation $\mathrm{H}: \mathrm{Q}$ ratio of the injured leg was not dependent on angular velocity and knee joint angle.

Acknowledgements. This study was supported by Research Council of Lithuania (MIP-10346).

\section{REFERENCES}

Aagaard, P., Simonsen, E. B., Magnusson, P. S., Larsson, B., Dyhre, P. (1998). A new concept for isokinetic hamstring: Quadriceps muscle strength ratio. The American Journal of Sports Medicine, 26 (2), 231-237.

Busch-Joseph, C. A., Debra, E., Patel, R. R. et al. (2001). Dynamic function after anterior cruciate ligament reconstruction with autologus patellar tendon. The American Journal of Sports Medicine, 29, 36-41.

Chmielewski, T. L., Stackhouse, S., Axe, M. J., SnyderMackler, L. (2004). A prospective analysis of incidence and severity of quadriceps inhibition in a consecutive sample of 100 patients with complete acute anterior cruciate ligament rupture. Journal of Orthopaedic Research, 22, 925-930.

Clair Gibson, A., Lambert, M. I., Durandt, J. J., Scales, N., Noakes, T. D. (2000). Quadriceps and hamstrings peak torque ratio changes in persons with chronic anterior cruciate ligament deficiency. Journal of Orthopaedic \& Sports Physical Therapy, 30 (7), 418-427.

Croce, R. V., Miller, J. P. (2006). Angle- and velocityspecific alterations in torque and semg activity of the quadriceps and hamstrings during isokinetic extensionflexion movements. Electromyography and Clinical Neurophysiology, 46 (2), 83-100.

Czamara, A., Tomaszewski, W., Bober, T., Lubarski, B. (2011). The effect of physiotherapy on knee joint extensor and flexor muscle strength after anterior cruciate ligament reconstruction using hamstring tendon. Medical Science Monitor, 17 (1), CR 35-41.

Devan, M. R, Pescatello, L. S, Faghri, P., Anderson, J. (2004). A prospective study of overuse knee injuries among female athletes with muscle imbalances and structural abnormalities. Journal of Athletic Training, 39 (3), 263-267.

Hewett, T. E., Myer, G. D., Zazulak, B. T. (2008). Hamstrings to quadriceps peak torque ratios diverge between sexes with increasing isokinetic angular velocity. Journal of Science and Medicine in Sport, 11 (5), 452459

Hiemstra, L. A., Webber, S., MacDonald, P. B., Kriellaars, D. J. (2004). Hamstring and quadriceps strength balance in normal and hamstring anterior cruciate ligament - reconstructed subjects. Clinical Journal of Sport Medicine, 14 (5), 274280 .

Holcomb, W. R., Rubley, M. D., Lee, H. J., Guadagnoli, M. A. (2007). Effect of hamstring emphasized resistance training on hamstring: Quadriceps strength ratios. The Journal of Strength \& Conditioning Research, 21, 41-47.

Itoh, H., Ichihashi, N., Maruyama, T., Kurosaka, M., Hirohata, K. (1992). Weakness of thigh muscles in individuals sustaining anterior cruciate ligament injury. Kobe Journal of Medical Sciences, 38 (2), 93-107.

Kannus, P. (1988). Ratio of hamstrings to quadriceps femoris muscles' strength in the anterior cruciate ligament insufficient knee: Relationship to long-term recovery. Physical Therapy, 69, 961-965.

Keays, S. L., Bullock-Saxton, J., Keays, A. C. (2000). Strength and function before and after anterior cruciate ligament reconstruction. Clinical Orthopaedic Research, $373,174-183$.

Lund-Hanssen, H., Gannon, J., Engebretsen, L., Holen, K., Hammer, S. (1996). Isokinetic muscle performance in healthy female handball players and players with a unilateral anterior cruciate ligament reconstruction. Scandinavian Journal of Medicine and Science in Sports, 6, 172-175.

Neeter, C., Gustavson, A., Thomeé, P., Augustsson, J., Karlsson J. (2006). Development of a strength test battery for evaluating leg muscle power after anterior cruciate ligament injury and reconstruction. Knee Surgery, Sports Traumatology, Arthroscopy, 14, 571-580.

Pua, Y. H., Bryant, A. L., Steele, J. R. et al. (2008). Isokinetic dynamometry in anterior cruciate ligament injury and reconstruction. Annals of the Academy of Medicine, 37, 330-340.

Risberg, M., Holm, I., Myklebust, C, Engebretsen, L. (2007). Neuromuscular training versus strength training during first 6 months after anterior cruciate ligament reconstruction: A randomized clinical trial. Physical Therapy Journal, 87, 737-750.

Rosene, J. M., Fogarty, T. D., Mahaffey, B. L. (2001). Isokinetic hamstrings: Quadriceps ratios in intercollegiate athletes. Journal of Athletic Training, 36 (4), 378-383. 


\title{
ŠLAUNIES RAUMENŲ JĖGOS MOMENTŲ IR JŲ SANTYKIO POKYTIS PRIEŠ PKR OPERACIJĄ IR PO REABILITACIJOS
}

\author{
Dovilè Parulytė ${ }^{1}$, Nerijus Masiulis ${ }^{1}$, Vaida Aleknavičiūtė ${ }^{1,2}$, Rima Solianik ${ }^{1}$, Gintarẻ Dargevičiūtė ${ }^{1}$, \\ Albertas Skurvydas ${ }^{1}$, Vytautas Streckis ${ }^{1}$ \\ Lietuvos kūno kultūros akademija ${ }^{l}$, Kaunas, Lietuva \\ Šiauliu kolegija², Šiauliai, Lietuva
}

\section{SANTRAUKA}

Tyrimo pagrindimas ir hipoteze. Kelio sąnario priekiniai kryžminiai raiščiai (PKR) - dažnai pažeidžiama kelio sąnario struktūra. Po PKR plyšimo suprastėja neuroraumeninè kontrolè, sutrinka sensomotorinè sistema (Risberg et al., 2007), raumenų aktyvacija ir sumažeja raumenų jẻga (Croce, Miller, 2006). Keleto mokslininkų atliktų tyrimų rezultatai parodè: po PKR plyšimo labiau sumažejja keturgalvio šlaunies raumens nei užpakaliniu šlaunies raumenu jèga (Busch-Joseph et al., 2001; Neeter et al., 2006). Taigi manytume, kad kelio tiesiamujų raumenu jègos sumažėjimas turi itakos keturgalvio ir užpakaliniu šlaunies raumenų santykiui (H:Q).

Tikslas: ištirti kelio tiesiamuju ir lenkiamujų raumenų izometrinès bei dinaminès jégos momento ir $\mathrm{H}: \mathrm{Q}$ santykio pokyčius prieš PKR operaciją ir po reabilitacijos.

Metodai. Tirta 10 fiziškai aktyvių vyrų, kurių PKR pažeisti. Testavimai atlikti prieš PKR rekonstruojamają operaciją ir po 3 ménesių reabilitacijos. Tiriamieji buvo testuojami izokinetiniu dinamometru. Išmatuotas maksimaliosios lenkimo ir tiesimo (esant $90^{\circ}, 60^{\circ} \mathrm{kampams}$ ) izometrinès kojų raumenu jègos momentas. Dinaminès jègos momentas tirtas esant $30,180,300 \%$ s kampiniams greičiams.

Rezultatai. Remiantis tyrimo rezultatais galima teigti, kad po reabilitacijos sumažejo pažeistos kojos izometrinès ir dinaminès jẻgos momento dydis. Sveikos kojos izometrinès lenkimo ir tiesimo jëgos momentas buvo didesnis nei pažeistos, tačiau po reabilitacijos pažeistos kojos tiesimo momentas mažesnis nei prieš operaciją.

Aptarimas ir išvados. PKR plyšimas daugiau turèjo itakos pažeistos nei sveikos kojos keturgalvio raumens jègos momento sumažèjimui prieš operaciją ir po reabilitacijos nei užpakalinių šlaunies raumenų. Po reabilitacijos pažeistos kojos H:Q santykis nepriklausè nuo greičio ir kelio sąnario kampo.

Raktažodžiai: maksimaliosios jẻgos momentas, raumenų pusiausvyra, raumenų susitraukimas.

Gauta 2010 m. lapkričio $18 \mathrm{~d}$.

Received on November 18, 2010

Corresponding author Dovilè Parulytė Lithuanian Academy of Physical Education Sporto str. 6, LT-44221 Kaunas Lithuania

Tel +37060695214

E-mail d.parulyte@1kka.lt 